\title{
Meningkatkan Hasil Belajar Kimia dengan Pendekatan Kooperatif Melalui Demonstrasi dan Kelompok Belajar Terbimbing pada Siswa SMA Negeri 1 Takalar
}

\author{
Muhsin \\ SMA Negeri 1 Takalar, Kabupaten Takalar - Provinsi Sulawesi Selatan \\ Corresponding Author. Email: muhsinsman1@gmail.com
}

\begin{abstract}
This study aims to improve students' chemistry learning outcomes with a cooperative approach through demonstrations and guided study groups. This research method uses classroom action research with research subjects are students of class X IPA2 SMAN 1 Takalar, amounting to 35 people. This research was conducted in two cycles and each cycle was conducted in four meetings including a test at the end of each cycle. Data were collected using observations and tests. The data obtained were analyzed using quantitative analysis and descriptive statistics. The results showed that the chemistry learning outcomes of class X IPA2 students of SMAN 1 Takalar could be improved with a cooperative approach through demonstrations and guided study groups with an average value of 73.00 (high category), and based on the observation results showed an increase in the frequency of student attendance and student activeness in following the learning process.
\end{abstract}

\begin{abstract}
Abstrak: Penelitian ini bertujuan untuk meningkatkan hasil belajar kimia siswa dengan pendekatan kooperatif melalui demonstrasi dan kelompok belajar terbimbing. Metode penelitian ini menggunaka penelitian tindakan kelas dengan subjek penelitian adalah siswa kelas $\mathrm{X}_{\mathrm{IPA}_{2}}$ SMAN 1 Takalar yang berjumlah 35 orang. Penelitian ini dilaksanakan sebanyak dua siklus dan setiap siklusnya dilakukan sebanyak empat kali pertemuan termasuk tes setiap akhir siklus. Pengambilan data dilakukan dengan menggunakan observasi dan tes. Data yang diperoleh dianalisis dengan menggunakan analisis kuantitatif dan statistik deskriptif. Hasil penelitian menunjukkan bahwa hasil belajar kimia siswa kelas $\mathrm{X}_{\mathrm{IPA}_{2}}$ SMAN 1 Takalar dapat ditingkatkan dengan pendekatan kooperatif melalui demonstrasi dan kelompok belajar terbimbing dengan nilai rata-rata sebesar 73,00 (kategori tinggi), dan berdasarkan hasil observasi menunjukkan adanya peningkatan frekuensi kehadiran siswa dan keaktifan siswa dalam mengikuti proses pembelajaran.
\end{abstract}

Article History

Received: 19-02-2021

Revised: 17-03-2021

Published: 14-04-2021

\author{
Key Words: \\ Learning Outcomes, \\ Cooperative, \\ Demonstration, Guided \\ Study Group,
}

\section{Sejarah Artikel}

Diterima: 19-02-2021

Direvisi: 17-03-2021

Diterbitkan: 14-04-2021

\section{Kata Kunci:}

Hasil Belajar, Kooperatif, Demonstrasi, Kelompok Belajar Terbimbing.

How to Cite: Muhsin, M. (2021). Meningkatkan Hasil Belajar Kimia dengan Pendekatan Kooperatif Melalui Demonstrasi dan Kelompok Belajar Terbimbing pada Siswa SMA Negeri 1 Takalar. Jurnal Teknologi Pendidikan : Jurnal Penelitian dan Pengembangan Pembelajaran, 6(1). doi:https://doi.org/10.33394/jtp.v6i1.3579

\section{Pendahuluan}

Kurangnya motivasi siswa dalam belajar dan rendahnya hasil belajar dapat di pengaruhi oleh berbagai faktor sebagai variabel yang esensial, seperti kesulitan siswa memahami konsep, cara verbal guru mengajar, penggunaan media belajar, berbagai sistem pembelajaran dan sebagainya (Nashirotun, 2020; Asni, 2017; Fajuri, 2019; Suarni, 2021). Rendahnya hasil belajar kimia dapat dipengaruhi oleh metode pembelajaran yang kurang bervariasi. Kenyataan yang ada di lapangan menunjukkan bahwa metode pembelajaran yang sering diterapkan oleh guru adalah ceramah yang pelaksanaannya lebih mengaktifkan 
aktivitas guru, sedangkan siswa cenderung pasif sehingga motivasi belajar siswa menurun dan akan berdampak terhadap hasil belajar yang dicapai. Berkaitan dengan hal tersebut, maka guru dituntut untuk menguasai konsep pelajaran dan metode mengajar yang sesuai dengan kondisi sekolah dan aspek psikologis peserta didik.

Berdasarkan pengalaman mengajar kimia di SMAN 1 Takalar, menunjukkan bahwa guru mengajar dengan menggunakan metode ceramah yang monoton sehingga aktivitas belajar siswa tidak terlalu maksimal dan akan berdampak terhadap rata-rata hasil belajar yang diperoleh siswa yaitu 6,05. Rata-rata nilai yang diperoleh siswa pada konsep redoks dan elektrokimia, menunjukkan kurang efektifnya pembelajaran yang diterapkan guru selama ini yaitu hanya menggunakan metode ceramah.

Konsep redoks dan elektrokimia menekankan penguasaan siswa dalam mengenal, menggunakan, dan membuat berbagai reaksi secara trampil dan terlatih. Melihat hasil belajar kimia siswa tersebut, seharusnya seorang guru dalam proses pembelajaran menggunakan suatu model pembelajaran yang bisa mengaktifkan dan mempercepat daya tangkap siswa dalam proses pembelajaran khususnya dalam menyelesaikan masalah yang diberikan oleh guru. Salah satunya adalah dengan menerapkan pembelajaran secara demonstrasi dan kelompok belajar terbimbing. Guru yang mengajar pada konsep redoks dan elektrokimia dengan menggunakan metode ceramah, dirasakan kurang tepat karena dalam pelaksanaan PBM guru lebih aktif, sedangkan siswa pasif mendengarkan penjelasan guru di depan kelas. Penggunaan metode demonstrasi dan kelompok terbimbing pada konsep redoks dan elektrokimia dirasakan cukup efisien dalam meningkatkan aktivitas belajar dan mengembangkan wawasan berfikir siswa. Guru menjelaskan materi redoks dan elektrokimia dengan menggunakan demonstrasi dan kelompok terbimbing akan mengaktifkan aktivitas belajar siswa sehingga diharapkan terjadi peningkatan hasil belajar siswa.

Mencermati proses pembelajaran dengan model pembelajaran demonstrasi dan kelompok terbimbing memberikan peluang besar kepada setiap siswa untuk lebih aktif sehingga motivasi untuk belajar yang diperoleh siswa setelah mengikuti proses pembelajaran. Adapun tujuan penelitian ini adalah untuk meningkatkan hasil belajar kimia dengan pendekatan kooperatif melalui demonstrasi dan kelompok belajar terbimbing pada siswa kelas X IPA 2 SMA Negeri 1 Takalar.

\section{Metode Penelitian}

Metode penelitian ini adalah penelitian tindakan kelas (Classroom Action Research) yang melibatkan refleksi diri yang berulang yaitu perencanaan, tindakan, pengamatan/observasi, refleksi dan perencanaan berulang. Subyek dalam penelitian ini adalah siswa kelas X IPA 2 SMAN 1 Takalar dengan jumlah siswa 35 orang. Penelitian tindakan kelas ini dilaksanakan dalam dua siklus yaitu siklus I dan siklus II. Pada siklus I dan II ini, guru akan mengajar siswa dengan menggunakan metode demonstrasi dan kelompok terbimbing pada konsep redoks dan elektrokimia. Sebelum memulai pengajaran, guru terlebih dahulu membagi siswa ke dalam kelompok-kelompok kerja dengan jumlah anggota kelompok 4-5 orang siswa, setelah kelompok terbagi guru akan memulai pengajaran dengan menggunakan metode demonstrasi yaitu menjelaskan definisi redoks dan elektrokimia, cara penyetaraan reaksi redoks di depan para peserta didik (siswa). Setelah guru selesai mendemonstrasikan konsep tersebut, maka siswa diberi kesempatan untuk melakukan sendiri kegiatan yang telah didemonstrasikan oleh guru di dalam kelompoknya, tetapi masih dalam pengawasaan dan bimbingan dari guru bidang studi. 
Sumber data dalam penelitian ini adalah siswa kelas X IPA2 SMAN 1 Takalar yang terdiri dari data kuantitatif berupa nilai tes hasil belajar yang diberikan setelah selesai siklus I dan siklus II. Selain itu juga akan diperoleh data kualitatif yaitu hasil pengamatan para obsever berupa aktivitas belajar siswa selama pembelajaran berlangsung yang meliputi: mendengarkan atau memperhatikan guru saat mengajar, membaca materi ajar dan menulis hal penting dari penjelasan guru, mengerjakan tugas yang diberikan oleh guru, berlatih untuk menggunakan redoks dan elektrokimia, dan mendemonstrasikan hasil kegiatan yang telah dilakukan. Data yang diperoleh dan pelaksanaan observasi dianalisis secara kualitatif, sedangkan data hasil belajar Kimia siswa Kelas X IPA2 SMAN 1 Takalar dianalisis secara kuantitatif dengan menggunakan statistik deskriptif.

\section{Hasil Penelitian Dan Pembahasan Deskripsi Siklus I}

Berdasarkan hasil analisis deskriptif, nilai tes hasil belajar kimia siswa Kelas X IPA 2 SMAN 1 Takalar setelah diterapkan model Demonstrasi dan Kelompok Belajar Terbimbing selama siklus I, maka diperoleh deskripsi nilai hasil belajar kimia siswa yang ditunjukkan pada tabel berikut:

Tabel 1. Nilai Tes Hasil belajar Siklus I
\begin{tabular}{|l|l|}
\hline Statistik & Nilai Statistik \\
\hline$\Sigma$ Subyek & 35 \\
Nilai Tertinggi & 80,00 \\
Nilai terendah & 46,67 \\
Rentang Nilai & 33,33 \\
Nilai Rata-rata & 67,03 \\
Standar Deviasi & 9,42 \\
\hline
\end{tabular}

Berdasarkan hasil analisis deskriptif, diperoleh informasi bahwa nilai rata-rata hasil belajar Siswa Kelas X IPA 2 SMAN 1 Takalar setelah proses belajar mengajar melalui model Demonstrasi dan Kelompok Belajar Terbimbing yang dilaksanakan pada Siklus I adalah 67,03 dengan standar deviasi 9,42 dari nilai ideal yang mungkin dicapai 100. Hal ini menunjukkan bahwa secara rata-rata kelas, tingkat penguasaan terhadap materi pelajaran yang diajar pada Siklus I sebesar $67,03 \%$ dan seluruh materi yang telah diberikan. Sedangkan secara individual, nilai yang dicapai siswa tersebar dan nilai minimum 46,67 dan nilai minimum ideal yang mungkin dicapai 0 sampai dengan nilai maksimum 80 dan nilai ideal yang mungkin dicapai 100 dengan rentang nilai 33,33. Dari rentang nilai yang diperoleh menunjukkan bahwa nilai perolehan siswa tersebar dan nilai rendah sampai nilai sangat tinggi. Jika nilai penguasaan siswa di atas dikelompokkan ke dalam lima kategori maka diperoleh distribusi frekuensi nilai seperti ditunjukkan pada Tabel 3 berikut ini.

Tabel 2. Distribusi Frekuensi dan Persentase Nilai Hasil Belajar Kimia Siswa Kelas X IPA2 SMAN 1 Takalar pada Siklus I.

\begin{tabular}{|l|l|l|c|c|}
\hline No & Nilai & Kategori & Frekuensi & Persentase (\%) \\
\hline 1 & $0-34$ & Sangat Rendah & 0 & 0 \\
2 & $35-54$ & Rendah & 3 & 8,57 \\
3 & $55-64$ & Sedang & 10 & 28.57 \\
4 & $65-84$ & Tinggi & 22 & 62.86 \\
5 & $85-100$ & Sangat Tinggi & 0 & 0 \\
\hline
\end{tabular}

Dari tabel di atas menunjukkan bahwa dari 40 orang siswa Kelas X IPA 2 SMAN 1 Takalar yang menjadi subjek penelitian, tidak ada siswa berada pada kategori sangat rendah, 
3 orang siswa berada pada kategori rendah, 10 orang siswa berada pada kategori sedang, 22 orang siswa berada pada kategori tinggi, dan tidak ada siswa yang berada pada kategori sangat tinggi.

Berdasarkan nilai rata-rata hasil belajar siswa yang diperoleh setelah proses belajar mengajar selama Siklus I berlangsung yaitu sebesar 67,03. Setelah dikategorisasikan berdasarkan tabel di atas, diketahui bahwa tingkat penguasaan siswa Kelas X IPA 2 SMAN 1 Takalar berada pada kategori tinggi. Apabila tes hasil belajar siswa pada siklus I kemudian dikategorikan dalam kriteria ketuntasan minimum yang berlaku di SMAN 1 Takalar untuk bidang studi Kimia, maka diperoleh persentase ketuntasan belajar siswa pada siklus I ini seperti pada tabel berikut ini.

Tabel 3. Deskripsi Ketuntasan Belajar Siswa Kelas X IPA2 SMAN 1 Takalar pada Siklus I.

\begin{tabular}{|l|l|c|c|}
\hline \multicolumn{1}{|c|}{$\begin{array}{c}\text { Kriteria } \\
\text { Ketuntasan }\end{array}$} & \multicolumn{1}{|c|}{ Kategori } & Frekuensi & $\begin{array}{c}\text { Persentase } \\
(\boldsymbol{\%})\end{array}$ \\
\hline $0-69$ & Tidak Tuntas & 16 & 45,71 \\
$70-100$ & Tuntas & 19 & 54,29 \\
\hline \multicolumn{2}{|c|}{ Jumlah } & 35 & 100,00 \\
\hline
\end{tabular}

Dari tabel diatas dapat dilihat bahwa persentase ketuntasan belajar siswa setelah diajar melalui model Demonstrasi dan Kelompok Belajar Terbimbing sebesar 54,29 \% atau 19 orang siswa dan 35 orang siswa termasuk dalam kategori tuntas dan 45,71\% atau 16 orang siswa dan 35 orang siswa termasuk dalam kategori tidak tuntas. Hal tersebut menunjukkan bahwa hampir setengah jumlah siswa perlu perbaikan karena belum mencapai kriteria ketuntasan minimum yang ditetapkan sekolah dan hal ini akan diusahakan pada siklus II.

Berdasarkan lembar observasi dan analisis data pada siklus I ditemukan beberapa siswa yang kurang aktif pada saat pembelajaran berlangsung, di mana siswa yang mengajukan diri untuk mengerjakan soal di papan tulis memiliki jumlah persentase hanya $15,83 \%$, siswa yang memberikan jawaban sementara ketika diberikan masalah di awal pembelajaran memiliki jumlah persentase hanya 10,83\%, dan masih banyak pula siswa yang kurang aktif untuk menanggapi jawaban dan kelompok lain pada saat diskusi berlangsung dengan jumlah persentase hanya $13,33 \%$. Pada tahap ini siswa yang memperhatikan materi yang diajarkan guru memiliki persentase hanya $72,50 \%$, hal ini berarti bahwa masih terdapat siswa yang ribut dan kurang memperhatikan pelajaran dengan jumlah persentase $22,50 \%$. Ini disebabkan oleh model pembelajaran yang berbeda dan sebelumnya, proses pembelajaran yang terlalu cepat, kurangnya bimbingan dalam pengerjaan soal-soal serta waktu yang diberikan untuk menyelesaikan soal tersebut terlalu singkat. Kurangnya pengelolaan kelas dan bimbingan baik secara perorangan ataupun secara kelompok sehingga siswa cenderung melakukan kegiatan lain pada saat proses pembelajaran berlangsung.

Selain itu pembagian anggota kelompok yang tidak merata antara siswa yang memiliki kemampuan berpikir tinggi, sedang dan kurang sehingga ada kelompok yang di dalamnya lebih banyak anggota kelompok yang memiliki kemampuan berpikir tinggi dan ada pula kelompok yang di dalamnya lebih banyak anggota kelompok yang memiliki kemampuan berpikir sedang sehingga kurang terjalin kerja sama antara anggota kelompok dalam mendiskusikan suatu masalah yang diajukan oleh guru. Hal ini nampak pada banyaknya siswa yang mengajukan solusi ataupun pertanyaan terhadap masalah yang diberikan masih tergolong rendah.

Oleh karena itu, pada siklus II dilakukan pembagian kelompok yang merata antara siswa yang memiliki kemampuan berpikir tinggi, sedang, dan rendah sehingga semua 
anggota kelompok dapat bekerja sama dengan baik dalam memecahkan suatu masalah yang diajukan oleh guru.

\section{Deskripsi Siklus II}

Berdasarkan hasil analisis deskriptif, nilai tes hasil belajar Kimia siswa Kelas X IPA 2 SMAN 1 Takalar setelah diterapkan pembelajaran melalui model Demonstrasi dan Kelompok Belajar Terbimbing selama siklus II, maka diperoleh deskripsi nilai hasil belajar kimia siswa yang ditunjukkan pada tabel 4 berikut ini.

Tabel 4. Nilai Tes Hasil belajar Siklus II

\begin{tabular}{|l|l|}
\hline Statistik & Nilai Statistik \\
\hline$\Sigma$ Subyek & 35 \\
Nilai Tertinggi & 86,64 \\
Nilai terendah & 63,33 \\
Rentang Nilai & 23,34 \\
Nilai Rata-rata & 73,00 \\
Standar Deviasi & 7,35 \\
\hline
\end{tabular}

Berdasarkan hasil analisis deskriptif diperoleh informasi bahwa nilai rata-rata hasil belajar siswa Kelas X IPA 2 SMAN 1 Takalar setelah proses belajar mengajar melalui model Demonstrasi dan Kelompok Belajar Terbimbing yang dilaksanakan pada Siklus II adalah 73,00 dengan standar deviasi 7,35 dari nilai ideal yang mungkin dicapai 100. Ini menunjukkan bahwa secara rata-rata kelas, tingkat penguasaan terhadap materi pelajaran yang diajar pada Siklus II sebesar $73,00 \%$ dari seluruh materi yang telah diberikan. Sedangkan secara individual, nilai yang dicapai siswa tersebar dari nilai minimum 63,33 dari nilai minimum ideal yang mungkin dicapai 0 sampai dengan nilai maksimum 86,67 dari nilai ideal yang mungkin dicapai 100 dengan rentang nilai 23,34. Jika nilai penguasaan siswa di atas dikelompokkan ke dalam lima kategori maka diperoleh distribusi frekuensi nilai seperti ditunjukkan pada Tabel 5 berikut ini:

Tabel 5 Distribusi Frekuensi dan Persentase Skor Hasil Belajar Siswa Kelas X IPA2 SMAN 1 Takalar pada Siklus II

\begin{tabular}{|l|l|l|c|c|}
\hline No & Nilai & Kategori & Frekuensi & Persentase (\%) \\
\hline 1 & $0-34$ & Sangat Rendah & 0 & 0 \\
2 & $35-54$ & Rendah & 0 & 0 \\
3 & $55-64$ & Sedang & 8 & 25,71 \\
4 & $65-84$ & Tinggi & 25 & 71,43 \\
5 & $85-100$ & Sangat Tinggi & 2 & 2,86 \\
\hline
\end{tabular}

Berdasarkan nilai rata-rata hasil belajar siswa yang diperoleh setelah proses belajar mengajar selama Siklus II berlangsung yaitu sebesar 73,00. Setelah dikategorisasikan berdasarkan tabel di atas, diketahui bahwa tingkat penguasaan Siswa Kelas X IPA 2 SMAN 1 Takalar berada pada kategori tinggi. Apabila tes hasil belajar siswa pada Siklus II kemudian dikategorikan dalam kriteria ketuntasan minimum yang berlaku di SMAN 1 Takalar untuk bidang studi kimia, maka diperoleh persentase ketuntasan belajar siswa pada Siklus II seperti pada tabel berikut ini.

Tabel 6. Distribusi Ketuntasan Belajar Siswa Kelas X IPA2 SMAN 1 Takalar pada Siklus II

\begin{tabular}{|c|c|c|c|}
\hline $\begin{array}{c}\text { Kriteria } \\
\text { Ketuntasan }\end{array}$ & \multicolumn{1}{|c|}{ Kategori } & Frekuensi & $\begin{array}{c}\text { Persentase } \\
(\boldsymbol{\%})\end{array}$ \\
\hline $0-69$ & Tidak Tuntas & 4 & 11,43 \\
\hline
\end{tabular}




\begin{tabular}{|c|l|c|c|}
\hline $70-100$ & Tuntas & 31 & 88,87 \\
\hline \multicolumn{2}{|c|}{ Jumlah } & 35 & 100,00 \\
\hline
\end{tabular}

Dari Tabel 6 dapat dilihat bahwa persentase ketuntasan belajar siswa setelah diajar melalui model Demonstrasi dan Kelompok Belajar Terbimbing dengan sebesar 88,87 \% atau 31 orang siswa dan 35 orang siswa termasuk dalam kategori tuntas dan 11,43\% atau 4 orang siswa dan 35 orang siswa termasuk dalam kategori tidak tuntas. Hal tersebut menunjukkan bahwa jumlah siswa yang berada dalam kategori tuntas mengalami peningkatan yakni, 31 orang atau 88,87 \% pada Siklus I kemudian naik menjadi 31 orang atau 77,50 \% pada Siklus II. Meskipun belum mencapai ketuntasan klasikal 80\%, namun penelitian ini menunjukkan peningkatan dari penelitian sebelumnya yang mencapai ketuntasan 76,67\% .

Berdasarkan hasil observasi yang menjadi rekaman pelaksanaan tindakan pada Siklus II dapat dipaparkan perubahan-perubahan sikap yang terjadi di dalam realisasi tindakan terhadap proses aktivitas belajar di kelas selama kegiatan berlangsung. Sikap siswa sudah menunjukkan antusias dalam mengikuti pelajaran bahkan sebagian siswa senang dengan model Demonstrasi dan Kelompok Belajar Terbimbing. Hasil pemberian tes dan hasil lembar observasi langsung selama proses pelaksanaan belajar mengajar selanjutnya dikomunikasikan dengan guru kimia (observer) untuk memperoleh tanggapan sekaligus mengetahui hasil akhir pelaksanaan tindakan atau penelitian.

Berdasarkan hasil tersebut terlihat adanya peningkatan persentase siswa yang memberikan jawaban sementara ketika diberi masalah di awal pembelajaran berlangsung yaitu dan 10,83\% meningkat menjadi $14,17 \%$, siswa yang mengajukan diri untuk mengerjakan soal di papan tulis dan pertemuan pertama siklus I hingga berakhirnya siklus II memiliki persentase $15,83 \%$ hingga mencapai $20,83 \%$, begitu pula dengan siswa yang menanggapi jawaban dan siswa lain meningkat persentasenya yaitu dan 13,33\% menjadi $15,83 \%$.

Frekuensi kehadiran siswa selama mengikuti kegiatan proses belajar mengajar sampai akhir pertemuan siklus II menggambarkan bahwa minat dan motivasi belajar kimiasiswa mengalami peningkatan, keberanian untuk mengajukan diri mengerjakan soal di papan tulis sudah merata bukan hanya pada golongan siswa yang mempunyai hasil belajar yang baik. Melainkan siswa yang selama ini diam memperlihatkan keberanian untuk maju mengerjakan soal-soal latihan di papan tulis dan mengajukan pendapatnya mengenai konsep yang ditanyakan. Kemampuan siswa dalam menerima materi pelajaran semakin meningkat. Hal ini dapat dilihat dari semakin berkurangnya siswa meminta penjelasan ulang materi yang sudah diberikan. Dengan demikian dapat dikatakan bahwa kualitas belajar mengajar pada siklus II ini semakin baik.

Adapun bentuk perubahan tindakan yang dilakukan pada siklus II yaitu menambah jumlah kelompok yang sebelumnya 5 kelompok yang terdiri dan 7 orang diubah menjadi 7 kelompok yang terdiri dan 5 orang, serta melakukan pertukaran anggota kelompok dengan cara membagi kelompok secara merata antara siswa yang memiliki kemampuan berpikir tinggi, sedang dan rendah. Hal ini dimaksudkan agar terjalin interaksi yang baik antar sesama anggota kelompok untuk mampu bekerja sama dalam memecahkan atau mendiskusikan suatu masalah yang diajukan oleh guru.

Selain itu, bentuk perubahan tindakan yang lain dilakukan adalah proses belajar mengajar yang tidak terlalu cepat, menambah waktu pengerjaan soal-soal penerapan tanpa mengurangi waktu pemberian materi pelajaran, memberikan kesempatan kepada siswa yang kurang berpartisipasi dan selalu main-main untuk mempersentasekan hasil diskusi kelompoknya, memberikan bimbingan kepada siswa, khususnya yang baru serius jika guru 
yang membimbing secara bergiliran dari satu kelompok ke kelompok yang lain, serta memberikan motivasi kepada siswa dengan cara mengemukakan bahwa siswa yang sering memberikan solusi terhadap pertanyaan yang diberikan oleh guru dan sering naik mengerjakan soal di papan tulis akan mendapatkan penambahan nilai.

\section{Kesimpulan}

Berdasarkan hasil penelitian yang telah dilakukan dapat disimpulkan bahwa penerapan model demonstrasi dan kelompok belajar terbimbing dapat meningkatkan hasil belajar kimia Kelas $\mathrm{X} \mathrm{IPA}_{2}$ SMAN 1 Takalar karena indikator keberhasilan telah terpenuhi. Dimana nilai ratarata pada siklus I adalah 67,03 dan meningkat menjadi 73,00.

\section{Saran}

Berdasarkan hasil pembahasan dan kesimpulan yang diperoleh dan penelitian ini, maka ada beberapa saran yang disampaikan sebagai berikut, yakni Guru diharapkan dapat menjadikan model Demonstrasi dan Kelompok Belajar Terbimbing sebagai suatu alternatif dalam mata pelajaran Kimia untuk meningkatkan hasil belajar kimia serta mengaktifkan siswa dalam proses pembelajaran.

\section{DAFTAR PUSTAKA}

Arifin, M. (2005). Strategi Belajar Mengajar Universitas Negeri Malang: Malang. Arikunto, S. (2008). Dasar-Dasar Evaluasi Pendidikan. PT. Bumi Aksara:Jakarta.

Asni, H. (2017). Upaya Meningkatkan Aktivitas dan Hasil Belajar Peserta Didik Melalui Penerapan Pendekatan Cooperative Learning Tipe Jigsaw di Kelas III-A SD Negeri 2 Cakrangeara. Jurnal Kependidikan: Jurnal Hasil Penelitian dan Kajian Kepustakaan di Bidang Pendidikan, Pengajaran dan Pembelajaran, 3(2). doi:https://doi.org/10.33394/jk.v3i2.567

DePorter, Bobbi, dkk. (2000). Quantum Teaching Mempratekkan Quantum Learning di Ruang-Ruang Kelas. Diterjemahkan oleh Ary Nilandari. Bandung: Penerbit Kaifa.

Fajuri, F. (2019). Penerapan Pendekatan Cooperative Learning Tipe Jigsaw dalam Upaya Meningkatkan Aktivitas dan Hasil Belajar Peserta Didik Kelas I SD Negeri 27 Ampenan. Jurnal Paedagogy, 6(1), 20-26. doi:https://doi.org/10.33394/jp.v6i1.2526

Haling, Abdul. (2006). Belajar dan Pembelajaran. Badan penerbit UNM: Makassar.

Hartono. (2008). Strategi Pembelajaran Aktif Learning. Diakses pada tanggal 15/1/2010 di http://edu-articles.eom

Nashirotun, B. (2020). Peningkatan Aktivitas dan Hasil Belajar Siswa dengan Metode Jigsaw dan Media Tubuh Manusia pada Pembelajaran IPA di MTs. Negeri 4 Klaten Jawa Tengah. Jurnal Paedagogy, 7(4), 402-407. doi:https://doi.org/10.33394/jp.v7i4.2945

Sabri, A. (2007). Strategi Belajar Mengajar Mikro Teaching. Quantum Teaching: Padang.

Syafruddin, dkk. (2005). Manajemen Pembelajaran. Quantum Teaching: Jakarta.

Sardiman. (2000). Interaksi \& Motivasi Belajar Mengajar. Rajawali Press: Jakarta.

Sudjana, N. (2005). Penilaian Hasil Proses Belajar mengajar. PT Remaja Rosdakarya: Bandung.

Suarni, G., Rizka, M., \& Zinnurain, Z. (2021). Analisis Pengaruh Penerapan Model Pembelajaran Sains Teknologi Masyarakat Terhadap Hasil Belajar Siswa. Jurnal Paedagogy, 8(1), 31-38. doi:https://doi.org/10.33394/jp.v8i1.3226

Uno, H.B. (2007). Model Pembelajaran Menciptakan Proses Belajar Mengajar yang kreatif dan Efektif PT. Bumi Aksara: Jakarta. 